Industria: Jurnal Teknologi dan Manajemen Agroindustri

ISSN 2252-7877 (Print) ISSN 2548-3582 (Online)

Tersedia online di http://www.industria.ub.ac.id https://doi.org/10.21776/ub.industria.Xxx.XXX.Xx.X

\title{
STRATEGI MITIGASI RISIKO PROSES PENGEMASAN MENGGUNAKAN METODE FAILURE MODES AND EFFECTS ANALYSIS (FMEA) DAN ANALYTICAL HIERARCHY PROCESS (AHP) (STUDI KASUS DI UD HARUM MANIS KOTA WISATA BATU)
}

\section{Risk Mitigation Strategies of Packaging Process Apple Chips using Failure Modes and Effects Analysis (FMEA) and Analytcal Hierarchy Process (AHP) Method (Case Study in UD Harum Manis Kota Wisata Batu)}

\author{
Abdel Rafi' Mufrodi ${ }^{1{ }^{*}}$, Usman Effendi ${ }^{2)^{*}}$ \\ 1) 2)* Universitas Brawijaya, Malang, Indonesia \\ *email_korespondensi: rafi_96@student.ub.ac.id \\ Diterima: hh/bb/tttt, Perbaikan 1: hh/bb/tttt, Perbaikan 2: hh/bb/tttt, Disetujui: hh/bb/tttt
}

\begin{abstract}
ABSTRAK
Keripik apel merupakan suatu produk agroindustri sebagai upaya agar apel segar dapat bertahan lama dengan memertahankan nilai gizi serta meningkatkan nilai jual/tambah. Penelitian ini bertujuan menganalisis risiko proses pengemasan, mengidentifikasi faktor-faktor yang menyebabkan terjadinya risiko, dan usulan strategi mitigasi pada proses pengemasan keripik apel. Metode Failure Mode and Effect Analysis (FMEA) sebagai alat identifikasi dan penilaian terhadap risiko proses pengemasan dan Analytical Hierarchy Process (AHP) sebagai alat dalam pembobotan alternatif strategi mitigasi risiko secara hirarki. Hasil penelitian menunjukkan nilai prioritas risiko tertinggi masingmasing variabel yaitu kemasan tidak tersegel rapat 209,8 dan kinerja operator berbeda-beda 111,6. Strategi mitigasi untuk mengurangi risiko proses pengemasan keripik apel yaitu tenaga kerja, dan pada masing-masing alternatif strategi mitigasi risiko training pekerja 0,47, menjalin kemitraan 0,32, dan peningkatan akses informasi 0,12 .
\end{abstract}

Kata kunci: AHP, FMEA, keripik apel, risiko proses pengemasan.

ABSTRAK

Apple chips is an agroindustry product as an effort to make fresh apples can last long by maintaining the nutritional value and the increase of the value selling/added. This research aims to analyze the risk of the packaging process, identify the factors that cause the occurrence of risk, and the proposed mitigation strategy in the process of packing apple chips. Method of Failure Mode and Effect Analysis (FMEA) as tools of identification and assessment of packaging process risk and Analytical Hierarchy Process (AHP) as tools in the weighting alternative hazard mitigation strategy alternative. The results showed, the highest risk priority number of each variable that is non-sealed packaging 208,9 and operator performance varies 111,6. The mitigation strategy to reduce the risk of packaging process apple chips is labour, and in each alternative risk mitigation strategy training workers' 0,47 , partnership 0,32 , and increased access to information 0,12 .

Keywords: AHP, apple chips, FMEA, packaging process risk. 
Judul artikel judul artikel...

\section{PENDAHULUAN}

Indonesia merupakan negara yang memiliki kekayaan akan Sumber Daya Alam (SDA) yang dimiliki berupa sektor pertanian, sektor perkebunan, sektor peternakan, dan sektor perikanan. Salah satu Sumber Daya Alam (SDA) yang dihasilkan adalah sektor pertanian, dimana pertanian menjadi kebutuhan pokok masyarakat itu sendiri. Dalam hal pemanfaatannya, diperlukan pengelolaan yang cermat dan profesional sehingga kekayaan alam yang dimiliki mampu meningkatkan kesejahteraan rakyat. Sektor pertanian terbagi atas tanaman pangan, hortikultura, perkebunan, dan kehutanan. Berdasarkan data yang dihimpun oleh Kementerian Pertanian (2014), hasil produksi tanaman hortikultura buah-buahan berjumlah 19.805.976 ton dengan luas panen $873.833 \mathrm{Ha}$, sedangkan tanaman hortikultura sayur-sayuran berjumlah 11.918.571 ton dengan luas panen 1.125.063 Ha.

Apel tidak hanya dikonsumsi langsung, tetapi diolah menjadi produk-produk turunan dari buah apel seperti keripik apel, jenang apel, sari buah apel, serta cuka apel. Hal ini termasuk upaya agar apel dapat bertahan lama, dengan memertahankan nilai gizi, serta meningkatkan nilai jual/tambah bagi apel. Salah satu produk yang digemari masyarakat adalah keripik apel. UD Harum Manis Kota Wisata Batu merupakan salah satu usaha yang bergerak dibidang agroindustri yang berdiri sejak 2003. Usaha ini terletak di 2 lokasi yaitu Jl. Raya Ir. Soekarno No. 48, Jl. Raya Mojorejo No. 67 dan terdapat 1 gudang untuk pembelian secara grosir di Jl. Sarimun Gang 1 No. 6 Desa Mojorejo, Kecamatan Junrejo, Kota Wisata Batu. Dikenal sebagai produsen, distributor, dan penjualan produk seperti Wingko Apel, Keripik Apel, Keripik Nangka, Keripik Salak, Keripik Ubi, Kerupuk Tahu, Jenang Apel, dan sebagainya. Hingga saat ini, produk andalan UD Harum Manis Kota Wisata Batu yaitu Wingko Apel dan Keripik Apel.

Keripik apel merupakan salah satu produk agroindustri yang enak, renyah, tahan lama, praktis, dan mudah dibawa, serta disimpan (Sukardi dkk., 2011). Dalam proses pengemasan keripik apel terdapat beberapa risiko yang sering dihadapi UD Harum Manis Kota Wisata Batu hingga saat ini. Beberapa risiko tersebut diantaranya fungsi label tidak dapat mewakili daya tarik konsumen yang berdampak pada pangsa pasar produk, pencetakan label tidak rata yang berdampak pada keinginan membeli produk oleh konsumen. 
Selanjutnya kebocoran kemasan, kemasan tidak tersegel rapat, rendahnya kualitas bahan pengemas, dan kesesuaian produk dengan jenis kemasan yang berdampak kepada produk didalam kemasan cepat rusak dikarenakan terdapat kontaminasi secara fisik dan kimia dan pemilihan jenis bahan pengemas yang aman untuk makanan (food grade), sebagaimana diketahui mayoritas produk jadi dalam kemasan masih terdapat kontaminan yang disebabkan migrasi bahan pengemas maupun dari pekerja/karyawan. Terakhir adalah kinerja operator berbeda-beda dan kurangnya pengawasan yang berdampak pada produktivitas keripik apel yang dihasilkan. Hal ini akan berdampak pada terkendalanya proses produksi keriik apel (Citraresmi dkk., 2016). Melatarbelakangi terdapat banyaknya risiko yang dihadapi, sehingga diperlukan mitigasi/respon untuk analisis lebih lanjut terkait risiko tersebut.

Upaya mitigasi/respon risiko dari proses pengemasan menggunakan metode yang digunakan yaitu Failure Mode and Effect Analysis (FMEA) yang merupakan salah satu metode sebuah teknik yang digunakan untuk mencari, mengidentifikasi, dan menghilangkan kegagalan potensial, error, dan masalah yang diketahui dari sistem, desain, proses, atau jasa sebelum hal tersebut sampai ke konsumen (Puspitasari \& Martanto, 2014). Hasil akhir dari metode Failure Mode and Effect Analysis FMEA) adalah nilai prioritas risiko/Risk Priority Number (RPN) berdasarkan tingkat keparahan kegagalan, frekuensi kejadian, dan kemampuan dalam mendeteksi kegagalan. Selanjutnya metode dalam menentukan alternatif strategi mitigasi/respon yaitu dikenal dengan Analytical Hierarchy Process (AHP) dimana metode ini memberikan solusi dalam membantu membuat keputusan oleh seorang decision maker dalam mengambil keputusan berdasarkan multikriteria yang akan diterapkan (Setiawan, 2009). Hasil akhir dari Analytical Hierarchy Process (AHP) nilai bobot (weights') kepentingan masing-masing alternatif yang tersedia.beberapa alternatif strategi untuk mitigasi/respon risiko proses pengemasan yaitu training pekerja, menjalin kemitraan, dan peningkatan akses informasi. Harapannya adalah dapat mengurangi risiko yang ada pada proses pengemasan dan memberikan dampak yang sangat positif bagi pelaku usaha.

Industria: Jurnal Teknologi dan Manajemen Agroindustri, X(X):XX-XX (20XX) 


\section{METODE PENELITIAN}

\section{Waktu dan Tempat Penelitian}

Penelitian ini dilaksanakan pada bulan September 2017 hingga bulan Oktober 2017. Pengolahan data dilaksanakan di Laboratorium Komputasi dan Analisis Sistem Jurusan Teknologi Industri Pertanian, Fakultas Teknologi Pertanian, Universitas Brawijaya, Malang. Data primer diperoleh melalui observasi, wawancara, dan pengisian kuesioner kepada 3 orang pakar/ahli dibidang produksi keripik apel UD Harum Manis Kota Wisata Batu.

\section{Prosedur Penelitian}

Penelitian ini secara umum diawali dengan survei pendahuluan. Selanjutnya dilakukan identifikasi masalah, sehingga diperoleh rumusan masalah dan tujuan. Selanjutnya adalah studi literatur, pengumpulan data hingga pengolahan dan analisis data. Selanjutnya pada tahap terakhir akan didapatkan kesimpulan dan saran. Secara sistematis, tahapan yang dilakukan dalam penelitian ini dapat dilihat pada Gambar 1.

\section{Identifikasi Variabel}

Terdapat 2 variabel yang digunakan dalam penelitian ini yaitu variabel produk dengan 6 indikator risiko yaitu fungsi label tidak dapat mewakili daya tarik konsumen, pencetakan label tidak rata, kebocoran kemasan, kemasan tidak tersegel rapat, kesesuaian produk dengan jenis kemasan, rendahnya kualitas bahan pengemas dan variabel tenaga kerja dengan 2 indikator risiko yaitu kinerja operator berbeda-beda dan kurangnya pengawasan. Identifikasi risiko berdasarkan observasi dan wawancara pihak terkait yaitu koordinator marketing UD Harum Manis Kota Wisata Batu. Risk drivers merupakan sebab dari kunci indikator faktor risiko dan risk impacts yang merupakan konsekuensi atau dampak dari terjadinya risiko kegagalan.

\section{Pengolahan Data menggunakan Metode Failure Mode and Effect Analysis (FMEA)}

Metode Failure Mode and Effect Analysis (FMEA) mengidentifikasi risiko berdasarkan Severity (Tingkat keparahan kegagalan), Occurrence (Frekuensi kejadian), dan Detection (Kemampuan dalam mendeteksi kegagalan). Pengolahan data dalam penulisan artikel ini disusun menggunakan software 
Judul artikel judul artikel...

Microsoft Excel 2010 (Microsoft Corp., USA) menggunakan komputer Acer (Acer Inc., Taiwan). Rumus yang digunakan yaitu (Santoso, 2007):

$$
\begin{aligned}
& R P N=S \times O \times D \\
& =\left(\sqrt[3]{S_{1} \times S_{2} \times S_{3}}\right) \times\left(\sqrt[3]{O_{1} \times O_{2} \times O_{3}}\right) \times\left(\sqrt[3]{D_{1} \times D_{2} \times D_{3}}\right)
\end{aligned}
$$

Keterangan:

$\mathrm{S}=$ Severity

$\mathrm{O}=$ Occurrence

$\mathrm{D}=$ Detection

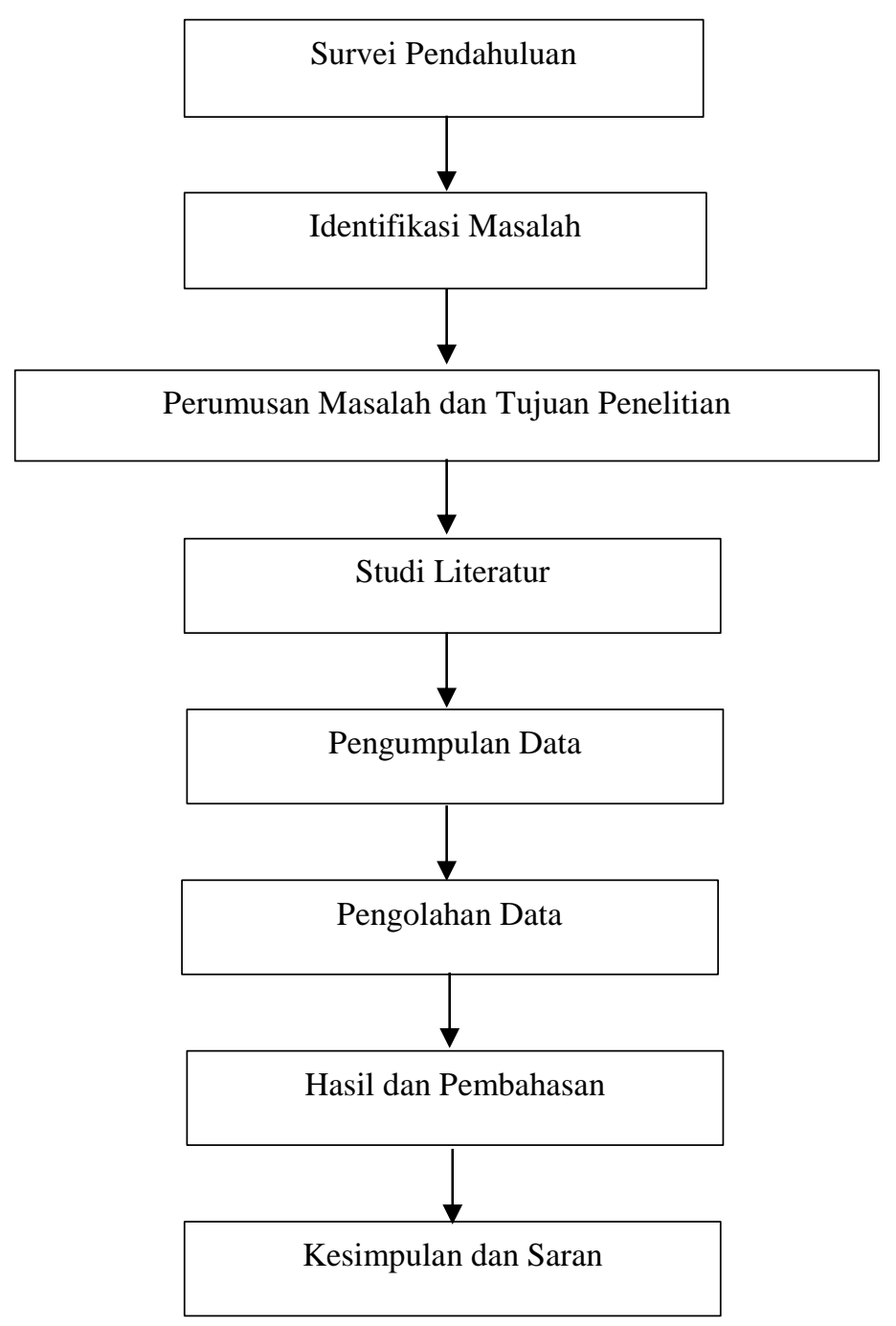

Gambar 1. Prosedur Penelitian 


\section{Pengolahan Data menggunakan Metode Analytical Hierarchy Process (AHP)}

Metode Analytical Hierarchy Process (AHP) digunakan dalam pengambilan keputusan terkait mitigasi/respon risiko proses pengemasan keripik apel. Pengambilan keputusan tersebut berdasarkan nilai bobot (weights') kepentingan secara total menggunakan perbandingan berpasangan (pairwise comparison). Pembobotan dilakukan berdasarkan nilai tertinggi hingga terendah, dimana nilai tertinggi merupakan alternatif yang dipilih secara total atau simultan. Pengolahan data dalam penulisan artikel ini disusun menggunakan software AHP Online System-BPMSG (Singapore) dan Microsoft Excel 2010 (Microsoft Corp., USA) menggunakan komputer Acer (Acer Inc., Taiwan). Langkah-langkah dalam pengambilan keputusan yaitu (Marimin, 2008):

a. Menentukan jenis-jenis kriteria yang akan menjadi persyaratan

b. Menyusun kriteria-kriteria tersebut dalam bentuk matriks perbandingan berpasangan (pairwise comparison)

Catatan:

Cara pengisian elemen pada matriks perbandingan berpasangan (pairwise comparison) adalah:

a. $\sum a[j, i]=1$ dimana $i=1,2,3, \ldots n$

b. Elemen matriks segitiga atas sebagai input Intensitas kepentingan

c. Elemen matriks segitiga bawah mempunyai rumus:

$$
a[j, i]=\frac{1}{a[j, i]} \text { untuk } i \neq j
$$

c. Menjumlah matriks kolom

d. Menghitung nilai $\sum$ kolom kriteria dengan rumus masing-masing elemen kolom dibagi dengan jumlah matriks kolom

e. Menghitung nilai prioritas kriteria dengan rumus menjumlah matriks baris hasil langkah ke-4 dan hasilnya dibagi dengan jumlah kriteria

f. Menentukan alternatif-alternatif yang akan menjadi pilihan 
g. Menyusun alternatif-alternatif yang telah ditentukan dalam bentuk matriks berpasangan untuk masing-masing kriteria, sehingga akan ada sebanyak $n$ buah matriks berpasangan antar alternatif

h. Masing-masing matriks berpasangan antar alternatif sebanyak $n$ buah matriks, masing masing matriksnya dijumlah per kolomnya.

i. Menghitung nilai prioritas alternatif masing-masing matriks berpasangan antar alternatif dengan rumus seperti langkah ke-4 dan langkah ke-5

j. Menguji konsistensi setiap matriks berpasangan antar alternatif dengan rumus masing-masing elemen matriks berpasangan pada langkah ke-2 dikalikan dengan nilai prioritas kriteria. Hasilnya masing-masing baris dijumlahkan dan hasilnya dibagi dengan masing-masing nilai prioritas kriteria sebanyak $\lambda_{1}, \lambda_{2}, \lambda_{3} \ldots \lambda_{\mathrm{n}}$

k. Menghitung $\lambda \max$ dengan rumus:

$$
\lambda \max =\frac{\sum \lambda}{n}
$$

1. Menghitung Indeks konsistensi (CI) dengan rumus:

$$
\text { CI } \lambda=\frac{\lambda \max -n}{n-1}
$$

m. Menghitung Rasio konsistensi (CR) dengan rumus:

$$
\mathrm{CR}=\frac{C I}{R I}
$$

n. Menentukan nilai Random Index (RI), berdasarkan banyaknya kriteria yang digunakan. Nilai RI dapat dilihat pada Tabel 1.

Tabel 1. Nilai Random Index (RI)

\begin{tabular}{ccccccccccc}
\hline $\mathbf{N}$ & $\mathbf{1}$ & $\mathbf{2}$ & $\mathbf{3}$ & $\mathbf{4}$ & $\mathbf{5}$ & $\mathbf{6}$ & $\mathbf{7}$ & $\mathbf{8}$ & $\mathbf{9}$ & $\mathbf{1 0}$ \\
\hline $\mathbf{R I}$ & 0,00 & 0,00 & 0,58 & 0,90 & 1,12 & 1,24 & 1,32 & 1,41 & 1,45 & 1,49 \\
\hline
\end{tabular}

Sumber: Saaty \& Vargas, (2012) 


\section{HASIL DAN PEMBAHASAN}

\section{Gambaran Umum Perusahaan}

UD Harum Manis Kota Wisata Batu berdiri sejak 2003 silam, yang merupakan salah satu usaha yang terkenal sebagai produsen, distributor, dan penjualan produk agroindustri, khususnya Kota Wisata Batu. UD Harum Manis memiliki 2 toko/outlet yang terletak di J1. Ir. Soekarno No. 48 Desa Mojorejo, Kecamatan Junrejo, Kota Wisata Batu dan Jl. Raya Mojorejo No. 67 Desa Beji, Kecamatan Junrejo, Kota Wisata Batu. Terdapat satu gudang produk khusus pembelian secara grosir yang terletak di Jl. Sarimun Gang 1 No. 6 Desa Beji, Kecamatan Junrejo Kota Wisata Batu. Ditinjau dari segi pemasaran produk, UD Harum Manis Kota Wisata Batu telah memasarkan produk siap jual hingga ke berbagai daerah dengan sistem pelayanan pesan antar ke berbagai daerah di Indonesia seperti Sumatera Selatan, DKI Jakarta, Kalimantan, hingga Sulawesi dengan pengelolaan saham merupakan kepemilikan keluarga.

UD Harum Manis Kota Wisata Batu memiliki slogan “Oleh-oleh Paling Uenak....” ini memiliki total pekerja \pm 46 orang karyawan/pekerja yang tergolong Perjanjian Kerja Waktu Tertentu (PKWT), dengan jam kerja dimulai pukul 07.00-21.00 WIB. Menurut Keputusan Menteri Tenaga Kerja dan Transmigrasi No. 100/MEN/IV/2004 tentang Pelaksanaan Perjanjian Kerja Waktu Tertentu, Perjanjian Kerja Waktu Tertentu (PKWT) adalah perjanjian kerja antara pekerja dengan pengusaha untuk mengadakan hubungan kerja dalam waktu tertentu atau untuk menyelesaikan suatu pekerjaan tertentu. Tujuan didirikan usaha ini karena untuk memudahkan para wisatawan dalam mencari buah tangan/oleh-oleh yang menjadi ciri khas Kota Wisata Batu. Secara umum, produk-produk yang dijual oleh UD Harum Manis Kota Wisata Batu yaitu Wingko Apel, Keripik Apel, Keripik Nangka, Keripik Salak, Keripik Nanas, Keripik Ubi, Kerupuk Tahu, Jenang Apel, dan sebagainya. Wingko apel merupakan inovasi produk terbaru dari wingko yang sudah ada sebelumnya. Dalam proses pembuatannya, diperlukan buah-buahan seperti apel, nangka, salak, dan durian sebagai bahan baku utama. Keripik apel sudah dikenal sejak lama sebagai oleh-oleh khas Kota Wisata Batu dengan merk dagang atas nama UD Harum Manis Kota Wisata Batu.

Industria: Jurnal Teknologi dan Manajemen Agroindustri, X(X):XX-XX (20XX) 
Judul artikel judul artikel...

UD Harum Manis Kota Wisata Batu telah mengambil langkah yaitu menjalin kemitraan dalam hal produksi keripik apel. Oleh karena itu, keripik apel yang ada di toko/outlet UD Harum Manis Kota Wisata Batu merupakan re-packaging keripik dengan merk dagang UD Harum Manis Kota Wisata Batu. Pihak mitra bertugas mendistribusikan keripik apel dengan berat bersih $5 \mathrm{~kg}$ (keripik apel loss). Pihak UD Harum Manis Kota Wisata Batu mengemas keripik apel berdasarkan kualitas 1 dengan merk dagang "keripik apel spesial" dan kualitas 2 dengan merk dagang "keripik apel tanpa kulit”. Kapasitas produksi keripik apel mencapai \pm 200 kg buah apel iris agar memenuhi permintaan konsumen dari UD Harum Manis Kota Wisata Batu. Proses repackaging ini dapat diartikan bahwa keripik apel kualitas 1 dan kualitas 2 dikelompokkan menjadi keseragaman ukuran dan bahan pengemas yang digunakan. Bahan pengemas yang digunakan yaitu alumunium foil dan plastik polipropilena untuk pengemas primer dan kardus bergelombang (corrugated cardboard) untuk pengemas sekunder.

\section{Identifikasi Risiko Proses Pengemasan Keripik Apel}

Penyebab risiko kegagalan pertama yaitu fungsi label tidak dapat mewakili daya beli konsumen, hal ini disebabkan dari kelengkapan atribut pada kemasan keripik apel yang masih dirasa kurang dan kurangnya ketelitian dari pekerja. Hal ini akan berdampak pada berkurangnya minat untuk membeli oleh konsumen terhadap produk keripik apel. Sebagaimana diketahui, keripik apel merupakan salah satu oleh-oleh/buah tangan khas Kota Wisata Batu. Penyebab risiko ke kedua yaitu pencetakan label tidak rata, hal ini disebabkan oleh kinerja alat/mesin pencetak yang dirasa masih kurang optimal, dipengaruhi oleh faktor usia alat/mesin yang sudah tua, dan kurangnya ketelitian dari pekerja. Oleh karena itu, berdampak pada waktu pencetakan label menjadi lebih lama dan target produksi tidak tercapai. Identifikasi risiko berdasarkan hasil brainstorming dapat dilihat pada Tabel 2.

Penyebab risiko kegagalan ketiga yaitu masih terdapat kebocoran kemasan keripik apel. Hal ini disebabkan oleh kinerja alat/mesin yang kurang optimal dan kurangnya kontrol terhadap alat/mesin tersebut. Oleh karena itu, dampak yang dirasakan UD Harum Manis Kota Wisata Batu adalah target produksi tidak tercapai. Penyebab risiko kegagalan keempat yaitu kemasan tidak tersegel rapat, hal ini disebabkan oleh pada 
Judul artikel judul artikel...

saat tahap pengisian produk ke dalam kemasan melebihi atau kurang dari standar dan keterampilan operator yang masih rendah. Hal ini dikarenakan latar belakang pendidikan dan motivasi yang dirasa masih rendah. Dampak yang dirasakan oleh pihak UD Harum Manis Kota Wisata Batu adalah target produksi keripik apel yang tidak tercapai. Penyebab risiko kegagalan kelima dan keenam yaitu kesesuaian produk dengan jenis kemasan dan rendahnya kualitas bahan pengemas yang digunakan, hal ini disebabkan oleh migrasi bahan pengemas ke dalam produk keripik apel yang termasuk ke dalam global migrasi. Menurut Balai Besar Kimia dan Kemasan (2014), global migrasi berarti total bahan hasil perpindahan semua komponen dari kemasan tanpa membedakan komponen tersebut berbahaya atau tidak bagi kesehatan.

Tabel 2. Identifikasi risk drivers dan risk impacts proses pengemasan keripik apel

\begin{tabular}{|c|c|c|}
\hline Indikator & Risk drivers & Risk impacts \\
\hline $\begin{array}{l}\text { Fungsi label tidak dapat } \\
\text { mewakili daya tarik konsumen }\end{array}$ & $\begin{array}{ll}\text { - } & \text { Kelengkapan atribut pada kemasan } \\
\text { keripik apel } & \\
\text { - } & \text { Kurangnya ketelitian dari pekerja }\end{array}$ & $\begin{array}{llc}- & \text { Berkurangnya minat untuk } \\
\text { membeli produk oleh konsumen }\end{array}$ \\
\hline Pencetakan label tidak rata & $\begin{array}{l}\text { - Kinerja alat/mesin pencetak yang kurang } \\
\text { optimal } \\
\text { - } \quad \text { Usia dari alat/komponen yang sudah tua } \\
\text { - } \quad \text { Kurangnya ketelitian dari pekerja }\end{array}$ & $\begin{array}{l}\text { - Waktu pencetakan label menjadi } \\
\text { lebih lama } \\
\text { - } \quad \text { Target produksi tidak tercapai }\end{array}$ \\
\hline Kebocoran kemasan & $\begin{array}{l}\text { - Kinerja alat/mesin pencetak yang kurang } \\
\text { optimal } \\
\text { - } \quad \text { Kurangnya kontrol alat/mesin }\end{array}$ & $\begin{array}{ll}\text { - } & \text { Kecacatan pada produk } \\
\text { - } & \text { Target produksi tidak tercapai }\end{array}$ \\
\hline Kemasan tidak tersegel rapat & $\begin{array}{l}\text { - Pengisian produk melebihi standar } \\
\text { - Keterampilan dari operator yang masih } \\
\text { rendah }\end{array}$ & Target produksi tidak tercapai \\
\hline $\begin{array}{l}\text { Kesesuaian produk dengan } \\
\text { jenis kemasan }\end{array}$ & $\begin{array}{l}\text { - Migrasi bahan pengemas ke dalam } \\
\text { produk }\end{array}$ & $\begin{array}{l}\text { Berkurangnya minat untuk } \\
\text { membeli produk oleh konsumen }\end{array}$ \\
\hline $\begin{array}{l}\text { Rendahnya kualitas bahan } \\
\text { pengemas }\end{array}$ & $\begin{array}{l}\text { - Migrasi bahan pengemas ke dalam } \\
\text { produk }\end{array}$ & $\begin{array}{l}\text { Berkurangnya minat untuk } \\
\text { membeli produk oleh konsumen }\end{array}$ \\
\hline Kinerja operator berbeda-beda & $\begin{array}{l}\text { - } \quad \text { Motivasi kerja operator yang kurang } \\
\text { - } \quad \text { Keterampilan dari operator yang kurang }\end{array}$ & $\begin{array}{l}\text { - Hasil akhir/output tidak sesuai } \\
\text { dengan kualitas dan kuantitas }\end{array}$ \\
\hline Kurangnya pengawasan & - Kurangnya ketelitian dari pekerja & $\begin{array}{l}\text { - Hasil akhir/output tidak sesuai } \\
\text { dengan kualitas dan kuantitas }\end{array}$ \\
\hline
\end{tabular}

Sumber: Data Primer, (2017)

Migrasi bahan pengemas disini seperti residu reaksi polimerisasi (monomer, katalis, dan pelarut), bahan tambahan/aditif (penyetabil rasa, plasticizer, dan filler) dan logam-logam berat $(\mathrm{Pb}, \mathrm{Cd}, \mathrm{Hg}, \mathrm{dan} \mathrm{Cr})$ menjadikan minat untuk membeli oleh konsumen menjadi berkurang. Dikatakan berkurangnya minat dikarenakan masih terdapat keripik yang tidak sesuai standar seperti tidak renyah, dan kondisi kenampakan 
Judul artikel judul artikel...

fisik dari keripik apel hancur. Penyebab risiko ke tujuh yaitu kinerja operator yang berbeda-beda, hal ini disebabkan motivasi kerja operator yang kurang dan keterampilan dari operator yang masih dirasa kurang. Penyebab risiko kegagalan kedelapan yaitu kurangnya pengawasan, hal ini disebabkan kurangnya ketelitian dari pekerja itu sendiri. Oleh karena itu, kedua risiko kegagalan ini akan dampak yang dirasakan yaitu hasil akhir/output tidak sesuai kualitas dan kuantitas. Dikatakan tidak sesuai kualitas dan kuantitas disini yaitu tidak mencapai target produksi yang telah ditetapkan oleh pihak UD Harum Manis Kota Wisata Batu.

\section{Analisis dan Strategi Mitigasi Risiko}

Dari Tabel 3., diperoleh nilai prioritas risiko/Risk Priority Number (RPN) terbesar dari variabel produk yaitu kemasan tidak tersegel rapat dengan nilai 208,9 dan variabel tenaga kerja yaitu kinerja operator berbeda-beda dengan nilai sebesar 111,6. Dalam penjabarannya, nilai prioritas risiko/Risk Priority Number (RPN) yaitu dimulai dari variabel produk dengan indikator kemasan tidak tersegel rapat diperoleh nilai Severity (Tingkat keparahan kegagalan) sebesar 6,0 yang berarti bahwa tingkat keparahan kegagalan pada mode moderate/sedang dengan keterangan sistem tidak dapat beroperasi dengan kerusakan kecil, sedangkan Occurrence (Frekuensi kejadian) dengan nilai 5,6 yang berarti bahwa frekuensi kejadian pada mode moderate/sedang dengan perbandingan kegagalan 1 dalam 80 produksi dan Defect (Kemampuan dalam mendeteksi kegagalan) 6,2 yang berarti bahwa kemampuan alat/tim pengontrol pada kategori rendah dalam mendeteksi penyebab kegagalan dan modus kegagalan berikutnya. Pada variabel produk nilai Severity (Tingkat keparahan kegagalan) yang masih dalam kategori moderate/sedang, hal tersebut dapat disebabkan dari kinerja alat/mesin kurang optimal dan kurangnya kontrol alat/mesin pada proses pengemasan, sehingga berdampak pada kecacatan pada produk dan target produksi tidak tercapai.

Pada variabel tenaga kerja dengan indikator kinerja operator berbeda-beda diperoleh nilai Severity (Tingkat keparahan kegagalan) sebesar 5,9 yang berarti bahwa tingkat keparahan kegagalan pada mode moderate/sedang. Nilai tersebut mencerminkan mode kegagalan sistem tidak dapat beroperasi dengan kerusakan kecil yang berdampak akan membahayakan keselamatan. Selanjutnya yaitu ditinjau dari nilai Occurrence (Frekuensi kejadian) dengan nilai 4,4 yang berarti bahwa frekuensi kejadian pada mode 
Judul artikel judul artikel...

moderate/sedang dengan perbandingan kegagalan 1 dalam 2.000 produksi, dan Defect (Kemampuan dalam mendeteksi kegagalan) dengan nilai 4,3 yang berarti bahwa kemampuan alat/tim pengontrol sangat sedang dalam mendeteksi penyebab kegagalan dan modus kegagalan berikutnya. Pada variabel tenaga kerja, nilai Severity (Tingkat keparahan kegagalan) yang masih dalam kategori moderate/sedang disebabkan oleh keterampilan dan kemampuan dari masing-masing operator berbeda, sehingga berdampak pada hasil akhir/output tidak sesuai dengan kualitas dan kuantitas. Oleh karena itu, diperlukan strategi mitigasi/respon dari nilai prioritas risiko/Risk Priority Number (RPN) tersebut.

Tabel 3. Hasil perhitungan nilai prioritas risiko/Risk Priority Number (RPN)

\begin{tabular}{|c|c|c|c|c|c|c|c|}
\hline Proses Produksi & Variabel & Indikator & $\mathbf{S}$ & $\mathbf{O}$ & D & RPN & $\begin{array}{c}\text { Ranking } \\
\text { (Peringkat) }\end{array}$ \\
\hline \multirow[t]{8}{*}{ Pengemasan } & Produk & $\begin{array}{l}\text { Fungsi label tidak dapat } \\
\text { mewakili daya tarik } \\
\text { konsumen }\end{array}$ & 1,6 & 3,6 & 3,6 & 20,0 & 6 \\
\hline & & $\begin{array}{l}\text { Pencetakan label tidak } \\
\text { rata }\end{array}$ & 2,4 & 6,9 & 5,8 & 97,5 & 3 \\
\hline & & Kebocoran kemasan & 2,3 & 4,9 & 4,2 & 46,8 & 5 \\
\hline & & $\begin{array}{l}\text { Kemasan tidak tersegel } \\
\text { rapat }\end{array}$ & 6,0 & 5,6 & 6,2 & 208,9 & 1 \\
\hline & & $\begin{array}{l}\text { Kesesuaian produk } \\
\text { dengan jenis kemasan }\end{array}$ & 3,5 & 4,3 & 6,3 & 93,9 & 4 \\
\hline & & $\begin{array}{l}\text { Rendahnya kualitas bahan } \\
\text { pengemas }\end{array}$ & 7,0 & 3,6 & 4,2 & 105,3 & 2 \\
\hline & $\begin{array}{l}\text { Tenaga } \\
\text { Kerja }\end{array}$ & $\begin{array}{l}\text { Kinerja operator berbeda- } \\
\text { beda }\end{array}$ & 5,9 & 4,4 & 4,3 & 111,6 & 1 \\
\hline & & Kurangnya pengawasan & 6,9 & 4,9 & 3,1 & 104,8 & 2 \\
\hline
\end{tabular}

Sumber: Data Primer (2007)

\section{Penyusunan Alternatif Strategi Mitigasi Risiko}

Tujuan dari penyusunan alternatif dalam penelitian ini adalah mitigasi/respon terhadap risiko kegagalan yang sedang dan akan terjadi. Strategi mitigasi/respon risiko proses pengemasan keripik apel dapat dilihat pada Tabel 4. Berdasarkan Tabel 4. diperoleh pencapaian dari beberapa alternatif strategi mitigasi/respon risiko proses pengemasan keripik apel. Dalam penyusunan alternatif strategi mitigasi/respon dimulai dari nilai rasio konsistensi atau Consistency Ratio (CR). Nilai rasio konsistensi diukur berdasarkan variabel yang 
Judul artikel judul artikel...

digunakan dalam penelitian ini terhadap seluruh responden. Nilai rasio konsistensi responden dapat dilihat pada Tabel 5. Ditinjau dari variabel yang digunakan, pada variabel produk dan variabel tenaga kerja masingmasing memiliki nilai rasio konsistensi (CR) 0,1\%. Menurut Saaty (2001), apabila nilai rasio konsistensi $(\mathrm{CR}) \leq 0,1 \%$ maka dianggap konsisten, sebaliknya jika nilai rasio konsistensi $(\mathrm{CR}) \geq 0,1 \%$ maka diperlukan perbaikan atau perhitungan ulang dari variabel yang digunakan. Oleh karena itu, diperoleh simpulan bahwa variabel yang digunakan dalam penelitian ini sudah sesuai kriteria dan dapat dikatakan valid.

Tabel 4. Strategi mitigasi/respon risiko proses pengemasan keripik apel

\begin{tabular}{|c|c|c|c|c|}
\hline \multicolumn{5}{|c|}{ Keterangan } \\
\hline Tujuan & & Mitigasi/respon risiko & & $\begin{array}{l}\text { Minimasi mode kegagalan pada produk dilihat dari } \\
\text { variabel produk dan tenaga kerja }\end{array}$ \\
\hline \multirow{2}{*}{\multicolumn{2}{|c|}{ Variabel }} & Produk & & $\begin{array}{l}\text { Mengurangi kegagalan pada proses pengemasan keripik } \\
\text { apel }\end{array}$ \\
\hline & & Tenaga kerja & & $\begin{array}{l}\text { Mengoptimalkan Sumber Daya Manusia (SDM) pada } \\
\text { proses pengemasan }\end{array}$ \\
\hline \multirow{3}{*}{$\begin{array}{l}\text { Alternatif } \\
\text { mitigasi risiko }\end{array}$} & \multirow[t]{3}{*}{ strategi } & Training pekerja & & Memberikan pelatihan/training bagi pekerja \\
\hline & & Menjalin kemitraan & & $\begin{array}{l}\text { Menjalin hubungan kerja/ kemitraan yang kuat dari } \\
\text { produsen bahan baku pengemas dan produsen dengan } \\
\text { produk sejenis }\end{array}$ \\
\hline & & $\begin{array}{l}\text { Peningkatan } \\
\text { informasi }\end{array}$ & akses & $\begin{array}{l}\text { Memberikan kemudahan dalam mendapatkan informasi } \\
\text { terkait keinginan dan kemudahan bagi konsumen serta } \\
\text { kebutuhan pekerja dalam melaksanakan tugas }\end{array}$ \\
\hline
\end{tabular}

Sumber: Data Primer (2017)

Tabel 5. Nilai rasio konsistensi (CR) responden

\begin{tabular}{llc}
\hline Tujuan & Variabel & Rasio konsistensi (CR) (\%) \\
\hline Mitigasi risiko & Produk & 0,1 \\
& Tenaga kerja & 0,1 \\
\hline
\end{tabular}

Sumber: Data Primer (2017)

Diperoleh nilai bobot (weights) kepentingan secara parsial dari yang tertinggi hingga terendah dari variabel produk, dimulai dari training pekerja sebesar 0,484, menjalin kemitraan sebesar 0,281, dan peningkatan akses informasi sebesar 0,235. Jika dilihat dari variabel tenaga kerja, nilai bobot (weights) kepentingan alternatif strategi mitigasi/respon risiko dimulai dari training pekerja sebesar 0,458 , menjalin kemitraan sebesar 0,400, dan peningkatan akses informasi sebesar 0,142. Jika dilihat nilai bobot (weights') kepentingan akhir alternatif strategi mitigasi/respon risiko dari mode kegagalan proses pengemasan dari 
Judul artikel judul artikel...

variabel tenaga kerja dengan nilai bobot (weights') kepentingan total sebesar 0,675 dengan alternatif yaitu training pekerja sebesar 0,47, menjalin kemitraan sebesar 0,32, dan peningkatan akses informasi sebesar 0,12. Nilai bobot (weights') kepentingan proses pengemasan keripik apel dapat dilihat pada Tabel 6. Setelah diperoleh nilai bobot (weights') kepentingan dapat digambarkan dalam struktur hirarki seperti pada Gambar 1.

Tabel 6. Nilai bobot (weights') kepentingan proses pengemasan keripik apel

\begin{tabular}{lccc}
\hline \multicolumn{1}{c}{ Alternatif } & Produk & Tenaga kerja & \multirow{2}{*}{ Bobot akhir } \\
\cline { 2 - 3 } & $\mathbf{0 , 3 2 5}$ & $\mathbf{0 , 6 7 5}$ & $\mathbf{0 , 4 7}$ \\
Training pekerja & 0,484 & 0,458 & 0,32 \\
Menjalin kemitraan & 0,281 & 0,400 & 0,12 \\
Peningkatan akses informasi & 0,235 & 0,142 & \\
\hline
\end{tabular}

Sumber: Data Primer (2017)

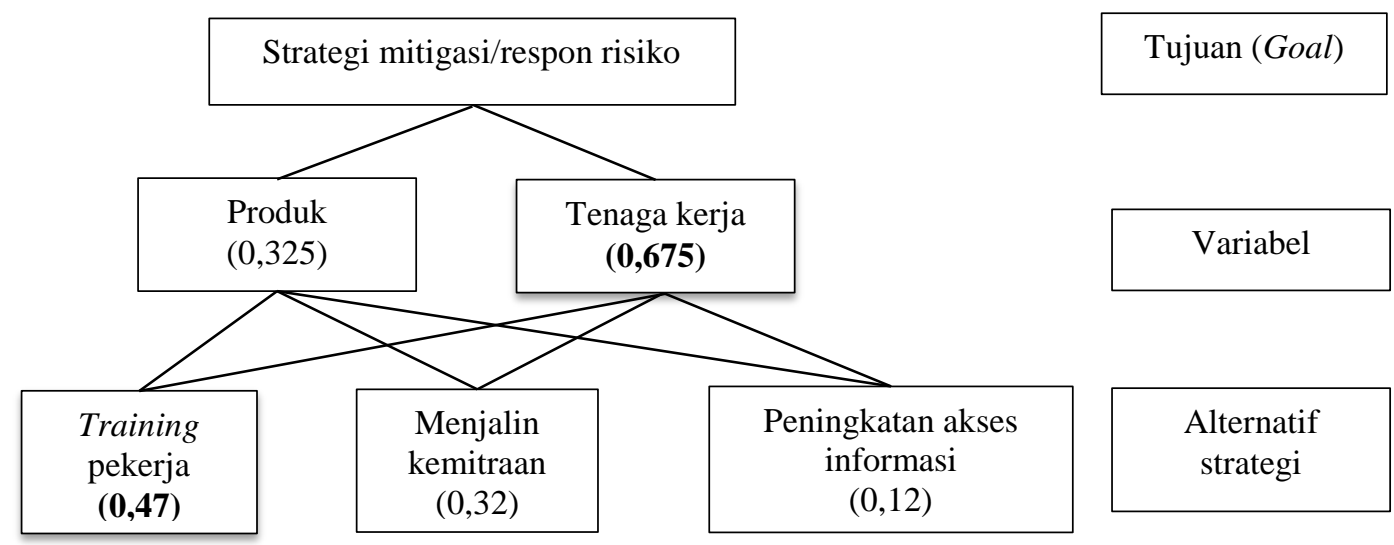

Gambar 1. Struktur hirarki pengambilan keputusan alternatif strategi mitigasi/respon risiko

$\underline{\text { Analisis Prioritas Tujuan terhadap Variabel }}$

Berikut penjabaran nilai bobot (weights') kepentingan terhadap variabel yang digunakan dalam penelitian ini. Nilai bobot (weights') kepentingan variabel produk sebesar 0,325 dan variabel tenaga kerja sebesar 0,675. Hasil analisis perhitungan menggunakan metode Analytical Hierarchy Process (AHP) nilai bobot (weights') kepentingan terhadap variabel dapat dilihat pada Tabel 7. 
Judul artikel judul artikel...

\section{Produk}

Variabel produk merupakan peringkat ke dua dengan nilai bobot (weights') kepentingan 0,325, sehingga menunjukkan bahwa kepentingan dari variabel produk terhadap proses pengemasan sebesar 0,325. Hal ini dikarenakan loyalitas konsumen terhadap produk masih dalam angka yang relatif tinggi dan jika dikaitkan dengan risiko kegagalan proses pengemasan, dianggap masih dalam batas standar. Menurut Nugroho (2015), terdapat beberapa dimensi produk terkait produk jadi yaitu dimulai dari kinerja (performance), daya tahan (durability), kesesuaian dengan spesifikasi (comformance to specifications), fitur (features), reliabilitas (reliability), estetika (aesthetics), dan kesan kualitas (perceived quality).

Tabel 7. Nilai bobot (weights') kepentingan terhadap variabel

\begin{tabular}{llcc}
\hline & Variabel & Bobot & Peringkat \\
\hline Produk & & 0,325 & 2 \\
Tenaga kerja & $\mathbf{0 , 6 7 5}$ & $\mathbf{1}$ \\
\hline
\end{tabular}

Sumber: Data Primer, (2017)

\section{Tenaga kerja}

Variabel tenaga kerja merupakan peringkat pertama dengan nilai bobot (weights') kepentingan 0,675, hal ini menunjukkan bahwa variabel tenaga kerja sangat penting terkait risiko kegagalan pada proses pengemasan keripik apel. Hal ini dikarenakan kemasan merupakan suatu bahan yang berinteraksi langsung dengan konsumen atau pelanggan di UD Harum Manis Kota Wisata Batu. Dalam upaya pencapaian tujuan tersebut, performansi dari para karyawan sangat memberikan dampak yang besar. Menurut Bernandin dan Russel (2005), performansi kinerja karyawan merupakan catatan outcome/keluaran yang dihasilkan dari fungsi suatu pekerjaan tertentu atau suatu kegiatan dalam suatu periode tertentu.

$\underline{\text { Analisis Prioritas Alternatif Strategi Mitigasi Risiko }}$

Setelah diperoleh alternatif strategi mitigasi/respon risiko terhadap variabel proses pengemasan keripik apel, berikut penjabaran nilai bobot (weights') kepentingan prioritas alternatif terhadap strategi mitigasi/respon dari risiko proses pengemasan yang diperoleh dari penelitian melalui responden. Nilai bobot (weights') kepentingan pada setiap alternatif strategi mitigasi/respon risiko yaitu training pekerja sebesar 0,47 , 
Judul artikel judul artikel...

menjalin kemitraan sebesar 0,32, dan peningkatan akses informasi sebesar 0,12. Berdasarkan hasil analisis menggunakan metode Analytical Hierarchy Process (AHP) dapat dilihat pada Tabel 8.

\section{Training pekerja}

Alternatif strategi pertama yaitu training pekerja dengan nilai bobot (weights') kepentingan sebesar 0,47. Training pekerja dapat dilakukan dengan cara memberikan pelatihan terhadap karyawan di UD Harum Manis Kota Wisata Batu khususnya pada proses pengemasan. Training dapat diberikan secara langsung maupun tidak langsung yang diselenggarakan pemerintah maupun lembaga swasta. Menurut Saaty (2001), tenaga kerja merupakan sekelompok orang yang mampu melakukan pekerjaan, baik didalam maupun diluar hubungan kerja, guna menghasilkan suatu barang atau jasa untuk memenuhi segala kebutuhan masyarakat. Harapan dilakukannya training pekerja ini agar dapat menambah ilmu pengetahuan para karyawan, soft skill dan hard skill dari para karyawan terkhusus proses pengemasan keripik apel. Karyawan dibagian proses pengemasan berjumlah 6 orang yang tergolong ke dalam Perjanjian Kerja Waktu Tertentu (PKWT). Dalam hal evaluasi dilakukan secara berkala oleh pihak perusahaan dengan mengukur performansi kinerja karyawan.

Para karyawan pada proses produksi khususnya proses pengemasan memiliki latar belakang pendidikan dan keterampilan yang rendah, dan mayoritas merupakan warga domisili Kota Wisata Batu dan sekitarnya, sehingga diperlukan pelatihan/training kepada para pekerja proses pengemasan. Selama ini, training pekerja dilakukan secara langsung (on the job training), dimana para pekerja diberikan pelatihan saat sedang bekerja. Pelatihan/training ini dilakukan secara informal oleh koordinator produksi hanya berdasarkan pengalaman, sehingga tidak memberikan dampak yang sangat signifikan terkait produk keripik apel siap jual. Menurut Sulistiana (2015), seluruh rangkaian proses produksi memerlukan bahan baku, tenaga kerja, modal, hingga alat/mesin penunjang kelancaran proses produksi.

\section{Menjalin kemitraan}

Alternatif strategi kedua yaitu menjalin kemitraan dengan nilai bobot (weights') kepentingan sebesar 0,32. Menjalin kemitraan ini dapat dilakukan dengan menjalin kerjasama terhadap produsen bahan baku pengemas yang digunakan, dan usaha sejenis yang diinginkan oleh UD Harum Manis Kota Wisata Batu. 
Judul artikel judul artikel...

Menurut Setiyadi dkk. (2011) salah satu prinsip dalam menjalin kemitraan adalah dilakukannya kerjasama kedua belah pihak atau lebih dengan tujuan yang sama dan senantiasa terus meningkatkan kualitas dan pelayan dari barang/jasa, efisiensi pemodalan, dan efektivitas waktu.

Kemitraan yang telah dilakukan UD Harum Manis Kota Wisata Batu hingga saat ini terkait pada faktor penting yaitu ketersediaan bahan baku kemasan yang yang bertindak sebagai distributor kemasan yang dibutuhkan untuk keberlangsungan proses produksi keripik apel. Jika ditinjau dari menjalin kemitraan terhadap produsen produk sejenis yaitu salah satu upaya dalam pemenuhan permintaan dari konsumen yang masin relatif tinggi. Dalam menjalin kemitraan dengan usaha sejenis, tidak terdapat surat perjanjian dimana pihak usaha sejenis bertindak selaku produsen dan distributor keripik apel untuk UD Harum Manis Kota Wisata Batu.

\section{Peningkatan akses informasi}

Alternatif strategi ketiga yaitu peningkatan akses informasi dengan nilai bobot (weights') kepentingan sebesar 0,12. Peningkatan akses informasi dapat dilakukan dengan memberikan kemudahan dalam mendapatkan informasi terkait keinginan konsumen serta kebutuhan pekerja dalam melaksanakan tugas dan kewajibannya. Jika ditinjau dari keinginan konsumen, keripik apel akan menjadi salah satu produk andalan oleh-oleh/buah tangan khas Kota Wisata Batu, sehingga pihak UD Harum Manis Kota Wisata Batu akan memberdayakan segala sumber daya yang ada untuk memaksimalkan proses produksi khususnya pada proses pengemasan. Hal ini akan berdampak pada produktivitas dari keripik apel itu sendiri (Sari dkk., 2016). Kemasan merupakan faktor utama, hal ini dikarenakan kemasan kontak langsung kepada konsumen adalah kemasan terlebih dahulu, dimulai dari atribut kemasan seperti pada label kemasan tersertifikasi label halal, tanggal kadaluarsa, desain label pada kemasan, komposisi produk, hingga berat bersih produk.

Jika ditinjau dari kemudahan dalam mendapatkan informasi ini akan berdampak pada loyalitas konsumen. Informasi yang diperoleh konsumen melalui media sosial atau media online, sehingga UD Harum Manis Kota Wisata Batu diharapkan dapat meningkatkan akses informasi secara langsung maupun tidak langsung. Informasi secara langsung diperoleh dari interaksi secara langsung, baik itu interaksi terhadap para 
Judul artikel judul artikel...

karyawan/pekerja di toko/outlet dan gudang, hingga testimoni terhadap para konsumen yang telah menjadi pelanggan UD Harum Manis Kota Wisata Batu, sedangkan informasi secara tidak langsung diperoleh dari testimonial konsumen melalui media sosial atau media online seperti terdapat situs milik UD Harum Manis Kota Wisata Batu dimana pengelolaan situs tersebut adalah karyawan dan koordinator marketing.

Jika ditinjau dari kebutuhan para pekerja khususnya proses pengemasan yaitu tersedianya Standard Operating Procedur (SOP) yang menjadi tata aturan terhadap pekerja dalam menyelesaikan tugas dan kewajibannya. Pertimbangan selanjutnya dalam peningkatan akses informasi bagi pekerja adalah latar belakang para pekerja khususnya proses pengemasan, hal ini dikarenakan mayoritas para pekerja memiliki pendidikan dan keterampilan yang rendah. Para pekerja tersebut mayoritas berdomisili disekitar UD Harum Manis Kota Wisata Batu. Upaya ini bertujuan untuk meningkatkan sisi perekonomian dari pekerja.

Tabel 8. Nilai bobot (weights') kepentingan terhadap prioritas strategi mitigasi/respon risiko

\begin{tabular}{lcc}
\hline \multicolumn{1}{c}{ Alternatif } & Bobot & Peringkat \\
\hline Training pekerja & $\mathbf{0 , 4 7}$ & $\mathbf{1}$ \\
Menjalin kemitraan & 0,32 & 2 \\
Peningkatan akses informasi & 0,12 & 3 \\
\hline
\end{tabular}

Sumber: Data Primer, (2017)

\section{Implikasi Manajerial}

Berdasarkan nilai bobot (weights') kepentingan total alternatif strategi mitigasi/respon risiko, diperoleh rekomendasi strategi yang dapat diterapkan oleh UD Harum Manis Kota Wisata Batu. Alternatif strategi dalam mengatasi permasalahan yang ada pada proses pengemasan di UD Harum Manis Kota Wisata Batu disusun berdasarkan penilaian secara kuantitatif dimulai dari nilai bobot (weights') kepentingan tertinggi sebagai berikut:

\section{Training pekerja}

UD Harum Manis Kota Wisata Batu diharapkan dapat melakukan pelatihan/training pekerja secara langsung (on the job training) maupun tidak langsung (off the job training). Hal ini atas dasar latar belakang para pekerja khususnya proses pengemasan yang memiliki tingkat pendidikan dan kemampuan yang masih rendah. Pelatihan/training pekerja secara langsung dapat dilakukan saat pekerja pada proses pengemasan 
Judul artikel judul artikel...

menjalankan tugas dan kewajibannya dan pelatihan/training secara tidak langsung (off the job training) dapat dilakukan pelatihan seperti workshop ataupun permainan outbond. Para pekerja yang berada di UD Harum Manis Kota Wisata Batu diharapkan dapat meningkatkan kemampuan, keahlian, dan keterampilan dari sebelumnya. Menurut Mangkuprawira (2003), pelatihan bagi karyawan merupakan sebuah proses pembelajaran, penmbahan ilmu pengetahuan dan skil tertentu serta sikap karyawan, dengan harapan para karyawan menjadi terampil dan mampu melaksanakan tugas dan tanggung jawab dengan baik.

\section{Menjalin kemitraan}

UD Harum Manis Kota Wisata Batu seharusnya menjalin kemitraan yang baik dengan emasok bahan baku pengemas dan usaha sejenis. Hal ini diharapkan dapat memerlancar proses produksi khususnya proses pengamasan terkait produk jadi siap kemas. Menurut Kurniawan dkk. (2013), menjalin kemitraan bertujuan untuk menjalin kerjasama dari dua belah pihak atau lebih dengan tujuan agar dapat mencapai tujuan bersama. Pola kemitraan yang dapat diterapkan adalah dengan pola dagang umum yang ditujukan untuk memerkuat hubungan kerjasama agar mendapatkan keripik apel sesuai kualitas.

\section{Peningkatan akses informasi}

Peningkatan akses informasi dapat dilakukan dengan memberikan kemudahan dalam mendapatkan informasi terkait keinginan konsumen dengan cara pemeliharan situs milik UD Harum Manis Kota Wisata Batu dan kebutuhan pekerja dalam melaksanakan tugas dan kewajibannya. Hal ini akan berdampak pada loyalitas konsumen dan tersedianya Standard Operating Procedur (SOP) yang menjadi tata aturan terhadap pekerja dalam menyelesaikan tugas dan kewajibannya. Pertimbangan selanjutnya dalam peningkatan akses informasi bagi pekerja adalah latar belakang para pekerja khususnya proses pengemasan. Mayoritas para pekerja berdomisili disekitar UD Harum Manis Kota Wisata Batu, hal ini bertujuan untuk meningkatkan sisi perekonomian dari pekerja. Menurut Sellanapan dan Palanikumar (2013), kemudahan dalam akses informasi bagi produk akan berbanding lurus terhadap laba yang akan diterima oleh suatu usaha. 


\section{KESIMPULAN}

Kesimpulan dari penelitian mengenai strategi mitigasi/respon risiko proses pengemasan keripik apel UD Harum Manis Kota Wisata Batu menggunakan metode Failure Mode and Effect Analysis (FMEA) dan Analytical Hierarchy Process (AHP) adalah:

1. Identifikasi risiko proses oengemasan menggunakan risk drivers dan risk impacts dengan faktor yangterdiri atas 2 variabel yaitu produk dan tenaga kerja. Dimulai dari variabel produk memiliki 6 indikator antara lain fungsi label tidak dapat mewakili daya tarik konsumen, pencetakan label tidak rata, kebocoran kemasan, kemasan tidak tersegel rapat, kesesuaian produk dengan jenis kemasan, dan rendahnya kualitas bahan pengemas, sedangkan pada variabel tenaga kerja memiliki 2 indikator antara lain kinerja operator berbeda-beda dan kurangnya pengawasan.

2. Pemeringkatan urutan prioritas risiko dimulai dari tertinggi hingga yang terendah antar variabel produk adalah kemasan tidak tersegel rapat dan dari variabel tenaga kerja adalah kinerja operator berbeda-beda.

3. Rekomendasi strategi mitigasi/respon variabel yang dipilih adalah tenaga kerja, dan rekomendasi agar dapat mengurangi risiko pada proses pengemasan dimulai dari training pekerja, menjalin kemitraan, dan peningkatan akses informasi.

\section{Daftar Pustaka}

Anonim. 2014 Statistik Hasil Produksi Hortikultura Tahun 2014. Dilihat 07 Desember 2017. < $\underline{\text { http:// }}$ hortikultura.pertanian.go.id/wp-content/uploads/2016/02/Statistik-Produksi-2014.pdf>

Anonim. 2014. Balai Besar Kimia dan Kemasan. Dilihat 07 Desember 2017. < http://bbkk.kemenperin.go.id/ v3/index.php >

Bernandin, H.J., \& Russel. 2010. Human Resource Management. New York: McGraw-Hill.

Citraresmi, A.D.P., Santoso, I., Deoranto, P., Mustaniroh., S.A., Rahayu, E.R., Ikasari, D.M., \& Silalahi, R.L.R. 2016. Perencanaan Kebutuhan Bahan Baku Keripik Apel pada UD Ramayana Agro Mandiri. Jurnal Teknologi Pertanian, 17(1):47-58 
Kurniawan, F., Zauhar, S., \& Hermawan. Kemitraan Pengelolaan Sektor Pariwisata (Studi pada Tirta Wisata Kabupaten Jombang). Jurnal Administrasi Publik, 1(1): 47-55.

Marimin. 2008. Teknik dan Aplikasi Pengambilan Keputusan Kriteria Majemuk. Jakarta: Grasindo.

Mangkuprawira, S. 2003. Manajemen Sumber Daya Manusia. Jakarta: Ghalia Indonesia.

Nugroho, N.T. 2015. Analisis Pengaruh Kualitas Produk, Harga, dan Promosi terhadap Keputusan Pembelian Air Mineral Kemasan (Studi Kasus Desa Tohudan, Colomadu, Karanganyar). Jurnal Duta Bangsa STMIK, $\underline{8(1): 1-7 .}$

Puspitasari, N.B., \& Martanto. 2014. Penggunaan FMEA dalam Mengidentifikasi Risiko Kegagalan Proses Produksi Sarung ATM (Alat Tenun Mesin) (Studi Kasus PT. Asaputex Jaya Tegal). J@TI Undip, 9(2): 93-98.

Saaty, T.L. 2001. Decision Making with Dependence and Feedback the Analytic Network Process, 2th Ed. USA: RWS Publications, 4922 Ellsworth Avenue Pittsburgh.

Sari, I.N., Lestari, E.R., \& Astuti, R. 2016. Analisis Produktivitas Sektor Kebun menggunakan Craig-Harris Productivity Model (Studi Kasus di PT Candi Loka-Kebun Teh Jamus). Jurnal Teknologi dan Manajemen, $\underline{5(2): 75-83}$

Sellanapan, N., \& Palanikumar, K. 2013. Modified Prioritization Methodology for Risk Priority Number in Failure Mode and Effect Analysis. International Journal of Applied Science and Technology, 3(4): 27-36.

Setiawan, A. 2009. Implementasi Aplikasi Decision Support System dengan Metode Analytical Hierarchy Process (AHP) untuk Penentuan Jenis Supplier. Jurnal Gaung Informatika, 2(2): 93-104.

Setiyadi, S., Amar, K., \& Aji, T. 2011. Penentuan Strategi Sustainability Usaha pada Usaha Kuliner menggunakan Metode SWOT-AHP. Jurnal Ilmiah Teknik Industri, 10(2): 68-77.

Sukardi., Effendi, U., \& Astuti, D.A. 2011. Aplikasi Six Sigma pada Pengujian Kualitas Produk di UKM Keripik Apel Tinjauan dari Aspek Proses. Jurnal Teknologi Pertanian, 12(1): 1-7.

Sulistiana, S.D. 2015. Pengaruh Jumlah Tenaga Kerja dan Modal terhadap Hasil Produksi Industri Kecil Sepatu dan Sandal di Desa Sambiroto Kecamatan Sooko Kabupaten Mojokerto. Skripsi. Universitas Negeri Surabaya. Surabaya. 